\title{
Ovarian cancer in children and adolescents: a rare disease that needs more attention.
}

T. Baert ${ }^{1,2}$, N. Storme ${ }^{1}$, E. Van Nieuwenhuysen ${ }^{1,2}$, A. Uyttebroeck ${ }^{3}$, N. Van Damme ${ }^{4}$, I. Vergote ${ }^{1,2}, \mathrm{~A}$. Coosemans ${ }^{1,2}$

${ }^{1}$ Department of Gynaecology and Obstetrics, UZ Leuven, Leuven, Belgium;

${ }^{2}$ Department of Oncology, Laboratory of Gynaecologic Oncology, KU Leuven, Leuven Cancer Institute, Belgium;

${ }^{3}$ Department of Paediatric Haemato-oncology, UZ Leuven, Leuven, Belgium;

${ }^{4}$ Belgian Cancer Registry, Brussels, Belgium

AC is supported by the Fund for Scientific Research Flanders (FWO-V)

TB and AC: concept design and writing of manuscript

AU, NS and NVD: data collection and manuscript revision

IV and EVN: manuscript revision

\section{Abstract}

Ovarian cancer is rare in childhood. This explains scattered literature reports and lack of specific pediatric treatment. This review gives an overview of the Belgian data from 20042013, as well as insight in the literature. Based on these findings, we propose the following strategy to index ovarian masses and malignancies in children better in the future: first of all, the improvement of worldwide data collection and second, the use of a reproducible definition of childhood, malignancy and ovarian mass.

\section{Ovarian cancer in children: a rare disease}

The most important childhood cancers are: leukemia, central nervous system tumors and neuroblastoma.[1] Tumors of the female genital tract in children and adolescents are rare. Amongst them, ovarian cancer is the most frequent one, in total $1 \%$ of all childhood 
cancers.[2] According to the SEER database (The Surveillance, Epidemiology and End Results of the National Cancer Institute, USA), 1.3\% of all ovarian cancers between 2008 and 2012 were diagnosed in patients below the age of 20 . This makes ovarian cancer in children extremely rare and therefore hard to study. Benign ovarian masses on the other hand are more frequent with approximately 2,6/100 000 girls each year.[3]

The distribution of pathology in ovarian cancer is different in children compared to adults (table 1). Ovarian cancer is the most important gynaecologic cancer in children, but a far second in adult women.[4] Epithelial ovarian carcinomas account for $90 \%$ of all ovarian cancers in adults. High-grade serous ovarian cancer (HGSOC) is the most frequent subtype. Prognosis of HGSOC remains poor. This explains the poor prognosis of ovarian cancer in adults. HGSOC metastasizes throughout the abdomen before causing symptoms, resulting in a diagnostic delay, leading to a poor prognosis. Nowadays, $80 \%$ of adult ovarian cancer patients still die. In children however, the most frequent ovarian cancer is non-epithelial. Most often, their ovarian cancers arise from germ cells (GCT). Less than $20 \%$ of ovarian cancers in children are epithelial in origin, with a predominance of serous and mucinous histology.[6,7] The overall prognosis of ovarian cancer in children is excellent compared to adults, because of a different histological distribution. [7,8] According to the study of Mangili G et al. reporting the largest database on ovarian germ cell, there are two important contributing factors to the prognosis of GCT: first, the majority (71\%) is detected at stage I and second, they respond well to surgery and chemotherapy leading to a 5 -year survival of $95.6 \%$ and $73.2 \%$ in stage I and advanced stages, respectively.[9] Because of this excellent prognosis of germ cell tumors, overall outcome of ovarian cancer in children is excellent compared to adults. 


\section{Literature review}

Table 2 and Figure 1 give an impression of the reported cases of ovarian childhood cancer in literature. $[8,10-41]$ It is clear that this only provides us a scattered overview of pediatric ovarian neoplasms, which is difficult to interpret. Each center publishes locally available data. The number of ovarian childhood cancers in the total amount of ovarian masses (both benign and malignant) differs enormously. On average, this results in a risk of malignancy of adnexal masses in children of $+/-19 \%$ with a range from 2 to $59 \%$. This is an enormous discrepancy. This difference cannot be explained by geographical differences alone. For this we see three additional causes: 1/Benign cysts and teratomas are often treated locally and not referred to a specialized pediatric oncologist and therefore will remain underreported. Thus artificially lowering the total amount of ovarian masses and artificially increasing the proportion of cancers, $2 /$ Differences in the study populations used in the case series. Some groups only report adnexal masses up to the age of 15 , as was done by Del Mar et al. while other groups include patients until the age of 19.[8] At this moment, children with cancer up to the age of 16 years are referred to a pediatric oncology unit, 3/ Terms and definitions used to describe ovarian masses differ from paper to paper. The golden standard for the diagnosis of an ovarian neoplasm is the ultrasound definition defined by the IOTA (International Ovarian Tumor Analysis) criteria: it is the part of an ovary or the total ovary that is not part of the normal ovarian physiology. [42]

Despite differences in reporting, it is clear from the Belgian data as from the literature data that there is a positive correlation of ovarian cancer with age (Figure 2). [8,14-32,34-41] Moreover, there might even be an underestimation of the incidence in older children, for reasons stated above. On the other hand, this finding might partially be explained by an increase in ovarian cancers after menarche. 


\title{
Management of ovarian cancer in children
}

\author{
* Germ cell tumors, the most common ovarian cancer
}

In 2014, the Gynecologic Cancer Intergroup (GCIG) formulated a consensus on ovarian germ cell tumors.[43] Since most tumors are unilateral and diagnosed as stage I disease, fertilitysparing surgery appears to be safe. In case of FIGO stage II disease or higher, surgery has to be extended, keeping in mind that the uterus usually can be preserved in case of a bilateral tumor. The administration of neoadjuvant chemotherapy, prior to debulking surgery (as is accepted in widespread epithelial ovarian cancer in adults [44]) can be considered in children with widespread dysgerminomas since the tumor is highly chemosensitive. Standard chemotherapy for advanced or incompletely resected GCT is BEP (Bleomycine, Etopiside, Cisplatinum q3w), alternatively JEB can be used in young children (Carboplatin replacing Cisplatin) or PEI (Cisplatin, Etoposide, Ifosfamide). Consequently, since more than $90 \%$ of children will survive their disease, the mapping and follow up of the side effects is of utmost importance. Most frequent side effects of $\mathrm{BEP} / \mathrm{JEB} / \mathrm{PEI}$ chemotherapy are lung toxicity from bleomycine, ototoxicity, neurotoxicity and kidney failure from cisplatin, tubular nefropathy from ifosfamide and the risk of acute myeloid leukemia or myelodysplastic syndrome in the case of etoposide. In a report from Zhang et al. there were no negative effects on fertility of BEP chemotherapy after fertility sparing surgery for GCT. $[45,46]$ Two studies by Matei $D$ et al. and Gershenson DM et al. reported no obvious physical adverse long-term events after treatment for GCT.[47,48]

\section{*Epithelial ovarian carcinoma: rare and lethal}

This cancer arises most frequently in the age group of $15-19$ years. In a report by Von Allmen et al. is stated that up to $20 \%$ of ovarian malignancies in children arise from the surface epithelium. In a subgroup of patients, high-grade serous ovarian cancer arises from precursor 
lesions called serous tubal intraepithelial carcinomas (STICS) that reside within the distal, fimbrial end of the fallopian tube for up to 5 years before progressing to invasive disease.[49] Prognosis for epithelial ovarian cancer in adolescents is better compared to adults, with $60 \%$ overall survival in the review of Kolwijck et al. describing ten advanced stage serous ovarian carcinomas in children[50]. This can be explained by tumor grade. The majority of epithelial ovarian cancers in children reported in literature are mucinous ovarian cancers or low-grade serous ovarian cancers. This is clearly different from the adult population, where the majority has a high-grade serous histology. Nevertheless, both for children and for adults, serous ovarian cancer will present most often at stage III or IV, with the typical features of a bloated abdomen, dyspnea and abdominal pain. Epithelial ovarian cancer in children is not restricted to serous and mucinous carcinoma: Deprest et al. described four clear cell ovarian carcinomas and one Brenner tumor and in the literature overview (table 2) an endometrioïd ovarian carcinoma [15], two small cell ovarian cancers of the hypercalcemic type $[19,38]$ and several sarcomas were reported.[19,30,35] Small cell ovarian carcinoma of the hypercalcemic type is a rare entity in ovarian cancer and has a propensity for the younger age group, but is not limited to children.[51] In contrast to the balanced and well reported treatment schedule for children with GCTs, epithelial ovarian cancer in children is treated as adults with a combination of surgery and platin-based chemotherapy.[44] In epithelial ovarian cancer, in contrast to pure dysgerminoma, it is however very important that all macroscopic tumor is resected. Therefore, fertility sparing surgery will be considered in theory, but will very often not be applicable if patients are diagnosed at stage II-IV.[52] However, the knowledge on epithelial ovarian cancer in children is scarce since they are only a minority of childhood ovarian cancers. Therefore, we believe it would be beneficial if these cases could be referred to pediatric gynecologic oncology centers and treated in international study protocols. 


\section{Belgian data}

In Belgium, all cancers are registered in a national database since 2004. (www.kankerregister.org) Absolute numbers and incidence rates are available until 2013 for all cancers in all age groups. Observed survival rates are calculated for all patients diagnosed between 2004 and 2013, with a last follow-up at the $1^{\text {st }}$ of July 2015.

Ovarian cancer in general is classified according to the ICD-10 classification (International Classification of Diseases, $10^{\text {th }}$ version). Ovarian pediatric cancer, including children until the age of 19, can be sub classified by using the ICCC-3 (International Classification of Childhood Cancer, $3^{\text {rd }}$ edition).[53] These classification systems are not identical. For example, juvenile granulosa cell tumors will be categorized differently according to the used classification system. The incidence of ovarian cancer in children in the different age groups per year, compared to the numbers in adults (ICD-10 classification used) is depicted in table 3 .

Between 2004 and 2013, 63 children and adolescents (0 to 19 years old), developed ovarian cancer on a total of 8604 ovarian cancers in Belgium $(0,7 \%)$. Of them $86 \%$ was 10 years or older. Table 4 further subclassifies the ovarian tumors in the pediatric population, using the ICCC-3 classification. Our data corresponds with literature that GCT are by far the largest group and that epithelial carcinomas are rare. As indicated in Table 1, GCT can be further subclassified in different groups, based on the degree of differentiation and the cellular components present in the tumor. Figure 3 gives an overview on the distribution of these subtypes for the Belgian childhood population. No choriocarcinomas were reported. Of note, metastatic lesions to the ovary and juvenile granulosa cell tumors were not registered as malignant lesions of the ovary in the Belgian database based on the ICCC-3 classification. 


\section{Conclusions and recommendations}

As ovarian cancer in children and adolescents remains a rare disease it is important to have a good registration and centralization. The majority of these cancers are GCT, which have often an excellent prognosis when treated correctly. However, data on epithelial ovarian cancer are limited and at this moment, there is no specific pediatric treatment. The existing data in literature are often contradictory and therefore not of real use for the clinical practice. To ameliorate this, we propose the following strategy:

1. Population wide data collection. The enormous efforts of the national cancer registers are of utmost importance. However, a transnational grouping of these cancers in a European or worldwide database will further improve our knowledge of the incidence of malignancy, without the bias of patient selection in referral clinics.

2. Consensus on the definitions to be used: what is an ovarian mass? How will we treat and classify tumors in adolescents and young adults? What is malignant and what is benign? It will be important not only to report the tumor type (germ cell vs sex cord stromal vs epithelial and other) but also to report the specific histopathological sub classification. This will be important information to interpret survival curves of children with ovarian cancer.

3. Participation in international clinical trials to determine prognostic factors and risk groups for treatment stratification; therapy descalation in low risk groups to improve quality of life and reduce long term sequellae.

\section{Highlights}

- GCT are the most frequent type of ovarian cancer in children and have an excellent prognosis 
- Epithelial ovarian cancer in children is very rare and therefore poorly studied. There is no specific treatment schedule and prognosis is clearly worse than for germ cell tumors

- Literature data are conflicting due to different classifications used and bias in reporting

- Collection of data nationwide and throughout Europe to improve our knowledge in this rare tumor type is recommended.

\section{Acknowledgements}

TB, IV and AC would like to thank the Olivia Hendrickx Research Fund (www.olivia.be) for their continuous support.

\section{References}

[1] American Cancer Society, Cancer Facts \& Figures 2013, Am. Cancer Soc. (2013).

[2] D. Von Allmen, Malignant lesions of the ovary in childhood, Semin. Pediatr. Surg. 14 (2005) 100-105. doi:10.1053/j.sempedsurg.2005.01.005.

[3] O. Lindfors, Primary ovarian neoplasms in infants and children : a study of 81 cases diagnosed in Finland and Sweden, Ann Chir Gynaecol suppl 1971; 177:1-6, 1971.

[4] V.W. Chen, B. Ruiz, J.L. Killeen, T.R. Coté, X.C. Wu, C.N. Correa, Pathology and classification of ovarian tumors., Cancer. 97 (2003) 2631-2642. doi:10.1002/cncr.11345.

[5] M. Morowitz, D. Huff, D. von Allmen, Epithelial ovarian tumors in children: a retrospective analysis, J. Pediatr. Surg. 38 (2003) 331-335. doi:10.1053/jpsu.2003.50103.

[6] J.D. Seidman, I. Horkayne-Szakaly, M. Haiba, C.R. Boice, R.J. Kurman, B.M. Ronnett, The Histologic Type and Stage Distribution of Ovarian Carcinomas of Surface Epithelial Origin, Int. J. Gynecol. Pathol. 23 (2004) 41-44. doi:10.1097/01.pgp.0000101080.35393.16.

[7] E. Van Nieuwenhuysen, S. Lambrechts, D. Lambrechts, K. Leunen, F. Amant, I. Vergote, Genetic changes in nonepithelial ovarian cancer, Expert Rev. Anticancer Ther. 13 (2013) 871-882.

[8] M. del Mar Andres, E. Costa, A. Canete, L. Moreno, V. Castel, Solid ovarian tumours in childhood: a 35-year review in a single institution, Clin Transl Oncol. 12 (2010) 287-291. doi:10.1007/s12094-010-0505-9.

[9] G. Mangili, C. Sigismondi, A. Gadducci, G. Cormio, P. Scollo, S. Tateo, et al., Outcome 
and risk factors for recurrence in malignant ovarian germ cell tumors: a MITO-9 retrospective study., Int. J. Gynecol. Cancer. 21 (2011) 1414-21.

doi:10.1097/IGC.0b013e3182236582.

[10] T.A. Junaid, Ovarian neoplasms in children and adolescents in Ibadan, Nigeria, Cancer. 47 (1981) 610-614. doi:10.1002/1097-0142(19810201)47:3<610::AIDCNCR2820470331>3.0.C0;2-A.

[11] M. Ehren, Benign and Malignant Ovarian Tumors in CM \& en and Adolescents, 29 (1981).

[12] P. Cronen, H.S. Nagaraj, Ovarian tumors in children, South. Med. J. 81 (1988) 464468.

[13] M.P. Diamond, J.W. Baxter, C.G. Peerman, L.S. Burnett, Occurence of Ovarian Malignancy in Childhood and Adolescence: A community-Wide Evaluation, Obstet. Gynecol. 71 (1988) 858 - 860.

[14] M. Gribbon, S.H. Ein, K. Mancer, Pediatric malignant ovarian tumors: a 43-year review., J. Pediatr. Surg. 27 (1992) 480-4. http://www.ncbi.nlm.nih.gov/pubmed/1326038.

[15] M. Brown, A. Hebra, K. McGeehin, A.R. III, Ovarian masses in children: a review of 91 cases of malignant and benign masses, J. Pediatr. Surg. 28 (1993) 930-932. http://www.sciencedirect.com/science/article/pii/002234689390700U.

[16] T. Van Winter, P.S. Simmons, K.C. Podratz, Surgically treated adnexal masses in infancy , childhood , and adolescence, Am. J. Obstet. Gynecol. 170 (1994) 17801789.

[17] A. Imai, T. Furui, T. Tamaya, Gynecologic tumors and symptoms in childhood and adolescence; 10-years' experience, Int. J. Gynecol. Obstet. 45 (1994) 227-234. doi:10.1016/0020-7292(94)90247-X.

[18] T. Major, GYNECOLOGY Ovarian malignancies in childhood and adolescence, Eur. J. Obstet. Gynecol. Reprod. Biol. 63 (1995) 65-68.

[19] S. Piippo, L. Mustaniemi, H. Lenko, R. Aine, J. Maenpaa, Surgery for ovarian masses during childhood and adolescence: a report of 79 cases., J. Pediatr. Adolesc. Gynecol. 12 (1999) 223-227. doi:10.1016/S1083-3188(99)00020-0.

[20] E. Freud, D. Golinsky, R.M. Steinberg, a Blumenfeld, I. Yaniv, M. Zer, Ovarian masses in children., Clin. Pediatr. (Phila). 38 (1999) 573-7. http://www.ncbi.nlm.nih.gov/pubmed/24157281.

[21] E.H. Quint, Y.R. Smith, Ovarian surgery in premenarchal girls., J. Pediatr. Adolesc. Gynecol. 12 (1999) 27-29.

http://eutils.ncbi.nlm.nih.gov/entrez/eutils/elink.fcgi?dbfrom=pubmed\&id=992 9837\&retmode=ref\&cmd=prlinks \npapers2://publication/doi/10.1016/S10833188(00)86617-6.

[22] J. Menczer, S. Sadetzki, H. Murad, G. Barda, H. Andreev, M. Barchana, Childhood and adolescent ovarian malignant tumors in Israel, Acta Obstet. Gynecol. Scand. 78 (1999) 813-817.

[23] C. Akyuz, A. Varan, N. Buyukpamukcu, T. Kutluk, M. Buyukpamukcu, Malignant ovarian tumors in children: 22 years of experience at a single institution, J. Pediatr. Hematol. Oncol. 22 (2000) 422-427. 
[24] D.L. Cass, E. Hawkins, M.L. Brandt, M. Chintagumpala, R.S. Bloss, A.L. Milewicz, et al., Surgery for ovarian masses in infants, children, and adolescents: 102 consecutive patients treated in a 15-year period, J. Pediatr. Surg. 36 (2001) 693699. doi:10.1053/jpsu.2001.22939.

[25] H. Martelli, C. Patte, Tumeurs des gonades chez l\&rsquo;enfant: Gonadal tumours in children, Arch. Pediatr. 10 (2003) 246-250. doi:10.1016/S0929693X(03)00038-1.

[26] E. Deligeoroglou, M. Eleftheriades, V. Shiadoes, D. Botsis, D. Hasiakos, A. Kontoravdis, et al., Ovarian masses during adolescence : clinical , ultrasonographic and ..., Gynecol. Endocrinol. 19 (2004) 1-8.

[27] K.A.P. Schultz, S.F. Sencer, Y. Messinger, J.P. Neglia, M.E. Steiner, Pediatric ovarian tumors: a review of 67 cases., Pediatr. Blood Cancer. 44 (2005) 167-73. doi:10.1002/pbc.20233.

[28] S. Islam, S.Z. Yamout, J.R. Gosche, Management and outcomes of ovarian masses in children and adolescents., Am. Surg. 74 (2008) 1062-5. http://www.ncbi.nlm.nih.gov/pubmed/19062661.

[29] U. Ryoo, D. Lee, D. Bae, B. Yoon, D. Choi, Clinical Characteristics of Adnexal Masses in Korean Children and Adolescents: Retrospective Analysis of 409 Cases, J Minim Invasive Gynecol. 17 (2010) 209-213. doi:10.1016/j.jmig.2009.12.013.

[30] S.-T. Yeap, C.-C. Hsiao, C.-S. Hsieh, H.-R. Yu, Y.-C. Chen, J.-H. Chuang, et al., Pediatric malignant ovarian tumors: 15 years of experience at a single institution., Pediatr. Neonatol. 52 (2011) 140-4. doi:10.1016/j.pedneo.2011.03.003.

[31] F.E. Al Jama, A. a Al Ghamdi, T. Gasim, S. a Al Dakhiel, J. Rahman, M.S. Rahman, Ovarian tumors in children and adolescents--a clinical study of 52 patients in a university hospital., J. Pediatr. Adolesc. Gynecol. 24 (2011) 25-8. doi:10.1016/j.jpag.2010.06.005.

[32] A.H. Loh, C.L. Ong, S.L. Lam, J.H. Chua, C.H. Chui, Pediatric risk of malignancy index for preoperative evaluation of childhood ovarian tumors, Pediatr. Surg. Int. 28 (2012) 259-266. doi:10.1007/s00383-011-3031-0.

[33] R. Khemakhem, Y. Ben Ahmed, W. Ben Ftina, F. Nouira, A. Charieg, S. Ghorbel, et al., Les kystes et tumeurs de l'ovaire chez l'enfant tunisien. Aspects diagnostiques et prise en charge thérapeutique, J. Pédiatrie Puériculture. 25 (2012) 8-13. doi:10.1016/j.jpp.2011.11.002.

[34] A. Ammor, M. Kisra, R. Oulahyane, M. Kababri, N. Maalmi, A. Cherkaoui, et al., Ovarian tumours in children : a review of 18 cases, African J. Paediatr. SurgeryAJPS. 9 (2012) 231-236. doi:10.4103/0189-6725.104726.

[35] C. Spinelli, V. Pucci, I. Buti, J. Liserre, A. Messineo, F. Bianco, et al., The role of tumor markers in the surgical approach of ovarian masses in pediatric age: a 10year study and a literature review., Ann. Surg. Oncol. 19 (2012) 1766-73. doi:10.1245/s10434-012-2249-y.

[36] M. Mukhopadhyay, R. Shukla, B. Mukhopadhyay, K. Mandal, A. Ray, N. Sisodiya, et al., Ovarian cysts and tumors in infancy and childhood, J. Indian Assoc. Pediatr. Surg. 18 (2013) 16-19.

[37] H. Liu, X. Wang, L. Donghao, Z. Liu, S. Gang, Ovarian masses in children and adolescents - an analysis of 521 clinical cases., J. Pediatr. Adolesc. Gynecol. 27 (2014) e73-7. doi:10.1016/j.jpag.2013.07.007. 
[38] B. Cribb, N. Vishwanath, V. Upadhyay, Paediatric ovarian lesions-the experience at Starship Children's Hospital, New Zealand, J. New Zeal. Med. Assoc. 127 (2014) 41-51.

[39] M. Zhang, W. Jiang, G. Li, C. Xu, Ovarian masses in children and adolescents - an analysis of 521 clinical cases., J. Pediatr. Adolesc. Gynecol. 27 (2014) e73-7. doi:10.1016/j.jpag.2013.07.007.

[40] S. Taskinen, R. Fagerholm, J. Lohi, M. Taskinen, Pediatric ovarian neoplastic tumors: incidence, age at presentation, tumor markers and outcome, Acta Obs. Gynecol Scand. 94 (2015) 425-429. doi:10.1111/aogs.12598.

[41] E. Péroux, S. Franchi-Abella, D. Sainte-Croix, S. Canale, F. Gauthier, H. Martelli, et al., Ovarian tumors in children and adolescents: A series of 41 cases., Diagn. Interv. Imaging. 96 (2014) 1-10. doi:10.1016/j.diii.2014.07.001.

[42] D. Timmerman, L. Valentin, T.H. Bourne, W.P. Collins, H. Verrelst, I. Vergote, Terms, definitions and measurements to describe the sonographic features of adnexal tumors: A consensus opinion from the International Ovarian Tumor Analysis (IOTA) group, Ultrasound Obstet. Gynecol. 16 (2000) 500-505. doi:10.1046/j.1469-0705.2000.00287.x.

[43] I. Ray-Coquard, J. Brown, P. Harter, D.M. Provencher, P.C. Fong, J. Maenpaa, et al., Gynecologic Cancer InterGroup (GCIG) Consensus Review for Ovarian Sex Cord Stromal Tumors, Int. J. Gynecol. Cancer. 24 (2014) S42-S47. doi:10.1097/IGC.0000000000000249.

[44] I. Vergote, C.G. Tropé, F. Amant, G.B. Kristensen, T. Ehlen, N. Johnson, et al., Neoadjuvant chemotherapy or primary surgery in advanced ovarian cancer., $\mathrm{N}$. Engl. J. Med. 363 (2010) 2371; author reply 2372.

[45] R. Zhang, Y.C. Sun, G.Y. Zhang, L.Y. Wu, J. Zuo, Treatment of malignant ovarian germ cell tumors and preservation of fertility., Eur. J. Gynaecol. Oncol. 33 (2012) 489-92. http://www.ncbi.nlm.nih.gov/pubmed/23185794 (accessed February 8, 2016).

[46] K. Mahadik, K. Ghorpade, Childhood Ovarian Malignancy, J. Obstet. Gynecol. India. 64 (2014) 91-94. doi:10.1007/s13224-014-0533-4.

[47] D. Matei, A.M. Miller, P. Monahan, D. Gershenson, Q. Zhao, D. Cella, et al., Chronic physical effects and health care utilization in long-term ovarian germ cell tumor survivors: a Gynecologic Oncology Group study., J. Clin. Oncol. 27 (2009) 41424149. doi:10.1200/JCO.2008.20.9189.

[48] D.M. Gershenson, A.M. Miller, V.L. Champion, P.O. Monahan, Q. Zhao, D. Cella, et al., Reproductive and sexual function after platinum-based chemotherapy in longterm ovarian germ cell tumor survivors: A gynecologic oncology group study, J. Clin. Oncol. 25 (2007) 2792-2797. doi:10.1200/JC0.2006.08.4590.

[49] S.H.L. George, P. Shaw, BRCA and Early Events in the Development of Serous Ovarian Cancer., Front. Oncol. 4 (2014) 5. doi:10.3389/fonc.2014.00005.

[50] E. Kolwijck, E.A. Boss, A.M. Van Altena, L. V Beex, L.F. Massuger, Stage IV epithelial ovarian carcinoma in an 18 year old patient presenting with a Sister Mary Joseph ' s nodule and metastasis in both breasts : A case report and review of the literature, Gynecol. Oncol. 107 (2007) 583-585. doi:10.1016/j.ygyno.2007.08.069.

[51] D.J. Taraszewski, Robert, Rosman, Paul M., Knight, Chris A., Cloney, CASE REPORT 
Small Cell Carcinoma of the Ovary, Gynecol. Oncol. 5 (1991) 149-151.

[52] J.Y. Tsai, P.E. Saigo, C. Brown, M.P. La Quaglia, Diagnosis, pathology, staging, treatment, and outcome of epithelial ovarian neoplasia in patients age $<21$ years, Cancer. 91 (2001) 2065-2070. doi:10.1002/10970142(20010601)91:11<2065::AID-CNCR1233>3.0.C0;2-R [pii].

[53] E. Steliarova-Foucher, C. Stiller, B. Lacour, P. Kaatsch, International classification of childhood cancer, third edition, Cancer. 103 (2005) 1457-1467. doi:10.1002/cncr.20910. 


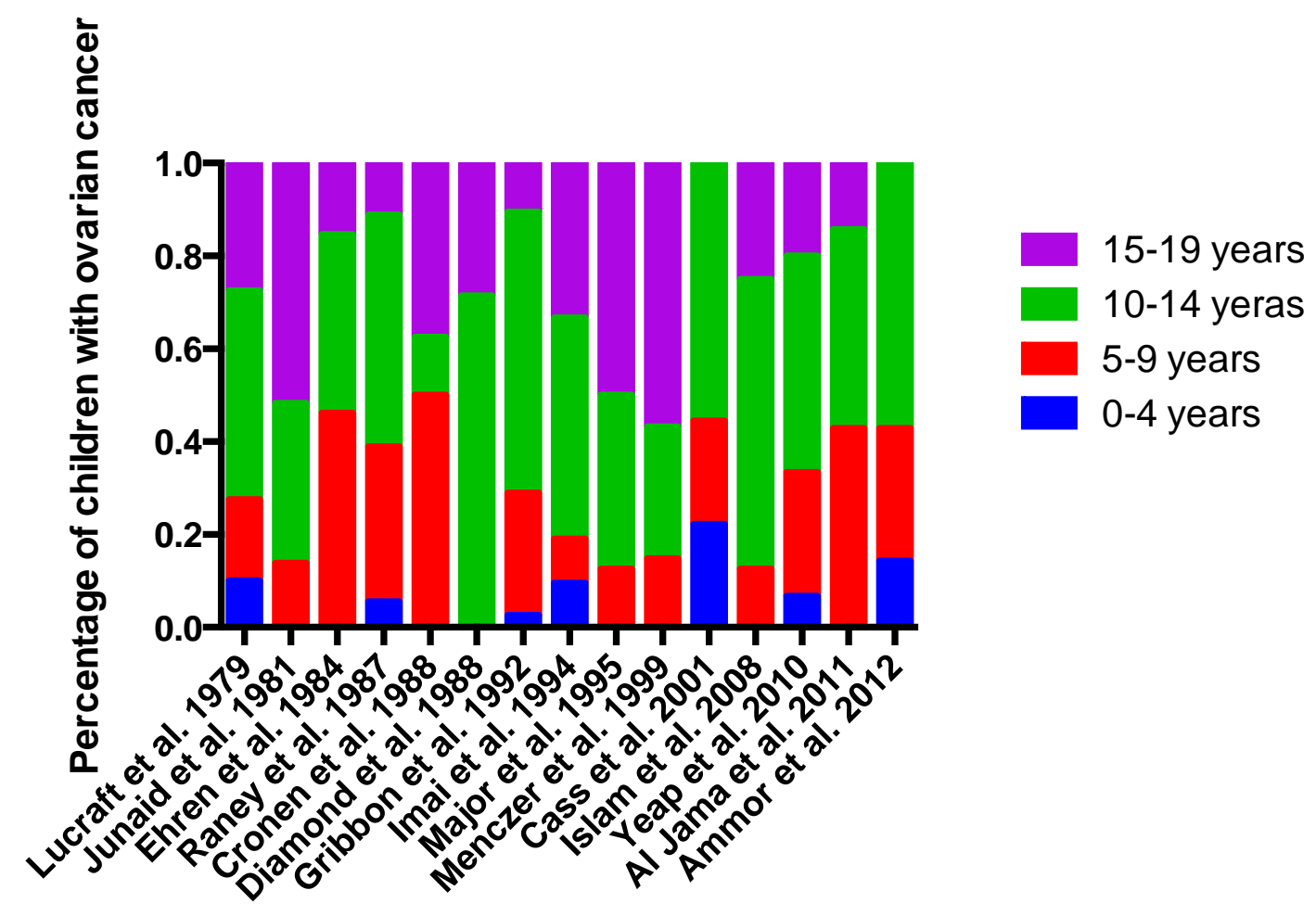

Figure 1. Age distribution of ovarian cancer cases in children in literature. Absolute numbers are shown. [8,10-41] 
A

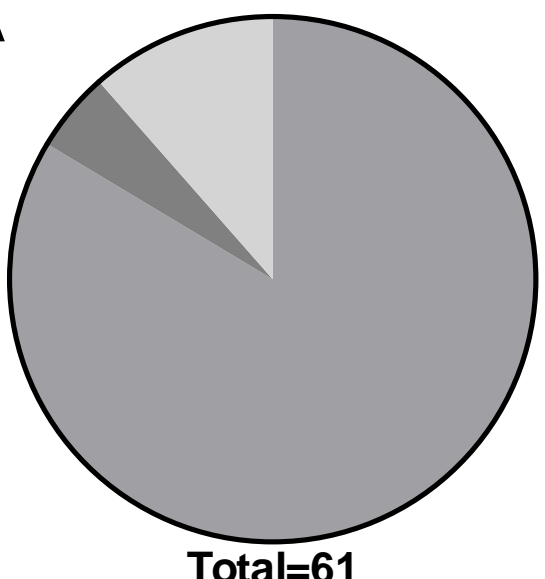

Total $=61$

B

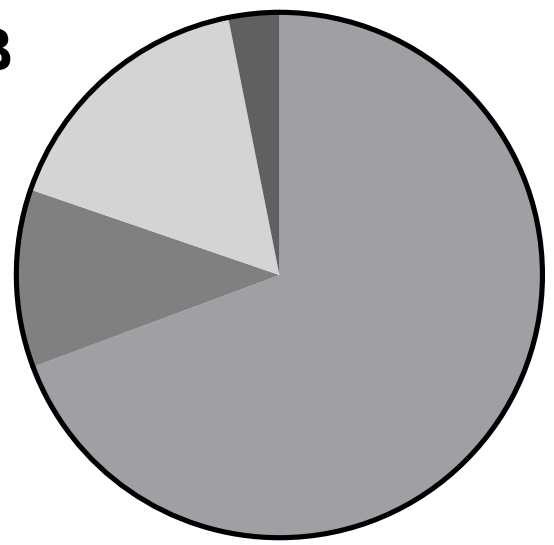

Total $=831$
$\operatorname{GCT}(83,6 \%)$

Sex cord stromal tumor (4,9\%)

Epithelial tumor $(11,4 \%)$ $\square \operatorname{GCT}(69,2 \%)$

$\square$ Sex cord stromal tumor $(11,4 \%)$

$\square$ Epithelial tumor (16,5\%)

$\square$ Other (3,3\%)

Figure 2 Distribution of different histological types of ovarian cancer derived from the Belgian data (A), literature (B).[8,19-23,30-45,47-52] Germ cell tumors are most frequent in both series, followed by epithelial tumors. 


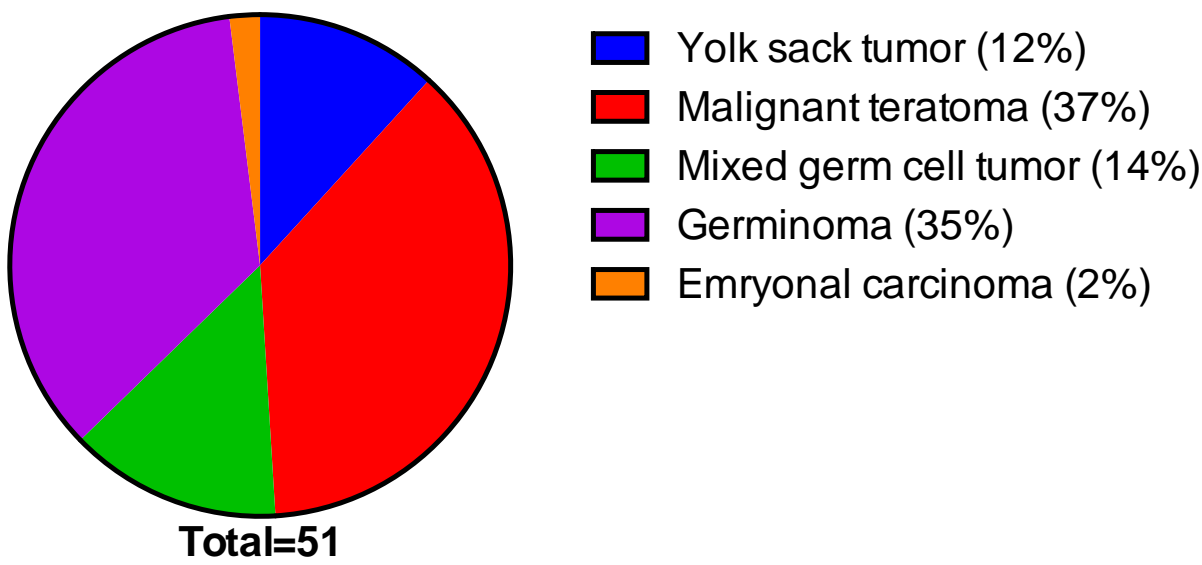

Figure 3 Distribution of GCT in Belgium based on the data of 2004-2013. 
Table 1 Classification of ovarian tumors according to the WHO classification

\begin{tabular}{|c|c|c|}
\hline \multirow{6}{*}{ Epithelial } & \multicolumn{2}{|c|}{ Serous } \\
\hline & \multicolumn{2}{|c|}{ Mucinous } \\
\hline & \multicolumn{2}{|c|}{ Endometrioid } \\
\hline & \multicolumn{2}{|c|}{ Clear cell } \\
\hline & \multicolumn{2}{|c|}{ Transitional cell } \\
\hline & \multicolumn{2}{|c|}{$\begin{array}{c}\text { Epithelial-stromal (adenosarcoma, } \\
\text { carcinosarcoma) }\end{array}$} \\
\hline \multirow{9}{*}{ Non-epithelial } & \multirow{5}{*}{ Germ cell } & Dysgerminoma \\
\hline & & Yolk sac \\
\hline & & Monodermal \\
\hline & & Mixed \\
\hline & & Teratoma \\
\hline & \multirow{3}{*}{ Sex Cord Stromal } & Granulosa cel tumor \\
\hline & & Sertoli-Leydig \\
\hline & & Mixed \\
\hline & \multicolumn{2}{|c|}{ Metastases } \\
\hline
\end{tabular}


Table 2 Overview of case series in literature from 1984-2014.

\begin{tabular}{|c|c|c|c|c|c|c|}
\hline Author, year & $\begin{array}{c}\text { Number } \\
\text { of } \\
\text { children } \\
\text { with } \\
\text { adnexal } \\
\text { masses }\end{array}$ & $\begin{array}{c}\text { Total number } \\
\text { of children } \\
\text { with ovarian } \\
\text { cancer }\end{array}$ & GCT & $\begin{array}{c}\text { Sex cord } \\
\text { stromal } \\
\text { tumor }\end{array}$ & $\begin{array}{c}\text { Epithelial } \\
\text { tumor }\end{array}$ & other* \\
\hline $\begin{array}{c}\text { Junaid et al. } \\
1981[26]\end{array}$ & 73 & 29 & 13 & 9 & 4 & 3 \\
\hline $\begin{array}{l}\text { Ehren et al. } \\
1984 \text { [27] }\end{array}$ & 63 & 13 & 12 & / & 1 & / \\
\hline $\begin{array}{c}\text { Cronen et al. } \\
1988 \text { [28] }\end{array}$ & 30 & 8 & 6 & 1 & 1 & / \\
\hline $\begin{array}{c}\text { Diamond et al. } \\
1988 \text { [29] }\end{array}$ & 137 & 7 & 5 & / & 2 & / \\
\hline $\begin{array}{c}\text { Gribbon et al. } \\
1992[30]\end{array}$ & NR & 38 & 29 & 6 & 2 & 1 \\
\hline $\begin{array}{c}\text { Brown et al. } \\
1993 \text { [19] }\end{array}$ & 91 & 22 & 14 & 3 & 4 & 1 \\
\hline $\begin{array}{l}\text { Van Winter et } \\
\text { al. } 1994 \text { [31] }\end{array}$ & 521 & 42 & 17 & 9 & 14 & 2 \\
\hline $\begin{array}{c}\text { Imai et al. } 1994 \\
{[32]}\end{array}$ & 114 & 21 & 14 & 4 & 3 & / \\
\hline $\begin{array}{c}\text { Major et al. } \\
1995 \text { [33] }\end{array}$ & NR & 16 & 11 & 1 & 3 & 1 \\
\hline $\begin{array}{l}\text { Piipo et al. } \\
1999 \text { [21] }\end{array}$ & 79 & 7 & / & 2 & 5 & / \\
\hline $\begin{array}{l}\text { Freud et al. } \\
1999[34]\end{array}$ & 34 & 8 & 4 & 3 & / & 1 \\
\hline $\begin{array}{l}\text { Quint et al. } \\
1999 \text { [35] }\end{array}$ & 52 & 5 & 1 & 1 & / & 3 \\
\hline $\begin{array}{c}\text { Menczer et al. } \\
1999[36]\end{array}$ & NR & 82 & 59 & 2 & 21 & / \\
\hline $\begin{array}{c}\text { Akyüz et al. } \\
2000[37]\end{array}$ & NR & 56 & 52 & 2 & 1 & 1 \\
\hline $\begin{array}{c}\text { Cass et al. } 2001 \\
{[38]}\end{array}$ & 102 & 9 & 6 & 3 & / & / \\
\hline
\end{tabular}




\begin{tabular}{|c|c|c|c|c|c|c|}
\hline $\begin{array}{c}\text { Martelli et al. } \\
2003 \text { [39] }\end{array}$ & 290 & 172 & 141 & 9 & 12 & 10 \\
\hline $\begin{array}{l}\text { Deligeorgoglou } \\
\text { et al. } 2004 \text { [40] }\end{array}$ & 44 & 1 & / & 1 & / & / \\
\hline $\begin{array}{l}\text { Schultz et al. } \\
2005 \text { [41] }\end{array}$ & 67 & 35 & 25 & 8 & 3 & I \\
\hline $\begin{array}{l}\text { Islam et al. } \\
2008 \text { [42] }\end{array}$ & 49 & 8 & 6 & 2 & / & I \\
\hline $\begin{array}{l}\text { Ryoo et al. } \\
2009 \text { [43] }\end{array}$ & 396 & 58 & 26 & 5 & 26 & 1 \\
\hline $\begin{array}{c}\text { Del Mar et al. } \\
2010[8]\end{array}$ & 53 & 27 & 21 & 5 & / & 1 \\
\hline $\begin{array}{l}\text { Yeap et al. } \\
2010 \text { [23] }\end{array}$ & NR & 15 & 14 & / & 1 & I \\
\hline $\begin{array}{c}\text { Al Jama et al. } \\
2011[44]\end{array}$ & 52 & 7 & 7 & / & / & / \\
\hline $\begin{array}{c}\text { Loh et al. } 2012 \\
\text { [45] }\end{array}$ & 78 & 11 & 6 & 3 & 2 & / \\
\hline $\begin{array}{c}\text { Khemakhen et } \\
\text { al. } 2012 \text { [46] }\end{array}$ & 31 & 1 & / & 1 & / & I \\
\hline $\begin{array}{c}\text { Ammor et al. } \\
2012 \text { [47] }\end{array}$ & 18 & 7 & 7 & / & / & / \\
\hline $\begin{array}{c}\text { Spinelli et al. } \\
2012[22]\end{array}$ & 120 & 5 & 3 & / & 2 & / \\
\hline $\begin{array}{c}\text { Liu et al. } 2013 \\
\text { [49] }\end{array}$ & 203 & 30 & 17 & 3 & 10 & / \\
\hline $\begin{array}{l}\text { Mukhopadhyay } \\
\text { et al. } 2013 \text { [48] }\end{array}$ & 49 & 33 & 32 & / & / & 1 \\
\hline $\begin{array}{l}\text { Cribb et al. } \\
2014 \text { [20] }\end{array}$ & 219 & 23 & 13 & 4 & 5 & 1 \\
\hline $\begin{array}{c}\text { Zhang et al. } \\
2014 \text { [50] }\end{array}$ & 521 & 60 & 32 & 8 & 21 & 1 \\
\hline $\begin{array}{c}\text { Taskinen et al. } \\
2015 \text { [51] }\end{array}$ & 45 & 13 & 10 & 1 & 1 & 1 \\
\hline $\begin{array}{c}\text { Peroux et al. } \\
2015 \text { [52] }\end{array}$ & 41 & 16 & 9 & 5 & 2 & / \\
\hline Total & 3572 & 885 & 612 & 101 & 146 & 29 \\
\hline
\end{tabular}


NR, not reported; GCT: germ cell tumor

*includes metastatasis from other tumors such as a localisation of a lymphoma in the ovary and gonadoblastomas 
Table 3. Number of cases of ovarian cancer (all histologies) per age group per year for Belgium. Classification of malignancy based on ICD-10 (International Classification of Disease)

\begin{tabular}{cccccc}
\hline Year & $\mathbf{0 - 4} \mathbf{y r}$ & $\mathbf{5 - 9} \mathbf{y r}$ & $\mathbf{1 0 - 1 4} \mathbf{y r}$ & $\mathbf{1 5 - 1 9} \mathbf{y r}$ & All ages \\
\hline $\mathbf{2 0 0 4}$ & 0 & 1 & 0 & 1 & 915 \\
$\mathbf{2 0 0 5}$ & 0 & 0 & 4 & 3 & 924 \\
$\mathbf{2 0 0 6}$ & 0 & 0 & 0 & 6 & 909 \\
$\mathbf{2 0 0 7}$ & 0 & 1 & 5 & 4 & 920 \\
$\mathbf{2 0 0 8}$ & 0 & 1 & 0 & 2 & 876 \\
$\mathbf{2 0 0 9}$ & 1 & 0 & 4 & 0 & 781 \\
$\mathbf{2 0 1 0}$ & 1 & 0 & 1 & 2 & 865 \\
$\mathbf{2 0 1 1}$ & 0 & 1 & 8 & 4 & 828 \\
$\mathbf{2 0 1 2}$ & 0 & 2 & 0 & 7 & 820 \\
$\mathbf{2 0 1 3}$ & 0 & 1 & 2 & 1 & 766 \\
T0TAL & $\mathbf{2}(\mathbf{0 , 0 2} \%)$ & $\mathbf{7}(\mathbf{0 , 0 8} \%)$ & $\mathbf{2 4}(\mathbf{0 , 2 8 \% )}$ & $\mathbf{3 0}(\mathbf{0 , 3 5 \% )}$ & $\mathbf{8 6 0 4}$ \\
\hline
\end{tabular}


Table 4. Sub classification of ovarian cancers in children (Belgian Cancer registry (2004 - 2013))

\begin{tabular}{|c|c|c|c|c|c|}
\hline & Total & $0-14 \mathrm{yr}$ & $15-19 \mathrm{yr}$ & $\begin{array}{c}1 \text { year } \\
\text { OS (\%) }\end{array}$ & $\begin{array}{c}5 \text { year } \\
\text { OS (\%) }\end{array}$ \\
\hline GCT & 51 & 29 & 22 & 100 & 89.4 \\
\hline $\begin{array}{c}\text { Malignant epithelial } \\
\text { tumor }\end{array}$ & 7 & 0 & 7 & - & - \\
\hline $\begin{array}{c}\text { Malignant sex cord } \\
\text { stromal tumor }\end{array}$ & 3 & 2 & 1 & - & - \\
\hline
\end{tabular}

GCT: germ cell tumor; OS: overall survival; -: not available 